\title{
Modeling the Choice of the Innovation and Investment Strategy for the Implementation of Modernization Potential
}

\author{
OLHA VOVK \\ Department of Air Transport Economics \\ National Aviation University \\ Kyiv, UKRAINE \\ MARYNA KRAVCHENKO \\ Dean of the Faculty of Management and Marketing \\ National Technical University of Ukraine "Igor Sikorsky Kyiv Polytechnic Institute" \\ Kyiv, UKRAINE \\ OLHA POPELO \\ Department of Management and Civil Service \\ Chernihiv Polytechnic National University \\ Chernihiv, UKRAINE \\ SVITLANA TULCHYNSKA \\ Department of Economics and Entrepreneurship \\ National Technical University of Ukraine "Igor Sikorsky Kyiv Polytechnic Institute" \\ Kyiv, UKRAINE \\ MARTA DERHALIUK \\ Department of Economics and Entrepreneurship \\ National Technical University of Ukraine "Igor Sikorsky Kyiv Polytechnic Institute" \\ Kyiv, UKRAINE
}

\begin{abstract}
Since modernization challenges of microeconomic systems are implemented through strategic management of the modernization potential development of enterprises, the rationale for choosing an exclusive innovation and investment strategy is proposed. An algorithm for making managerial decisions based on the model of "preferences in the implementation of investment and innovation strategies" ("PIIIS") is built. The model is based on the concept of strategic management, economic and mathematical hierarchy of potential levels of cognitive judgment, optimization of resources on demand and the structure of innovation and investment strategies. This allows to ensure the efficiency and resource conservation of individual innovation and investment strategies in modernization potential of the enterprise. The sequence of establishing preferences of innovation and investment strategies for activating modernization potential of microeconomic systems is proposed. To model the process of granting preferences to innovation and investment strategies, a system of coefficients based on the potential profile level using cognitive judgments is substantiated. Resource-providing, accumulating, implementation and resulting levels of the modernization potential development are singled out. According to the profile levers, target tasks and alternatives of preferences of innovation and investment strategies for the modernization potential development are identified. Decomposition of tasks of granting preferences to innovation and investment strategies to intensify modernization potential of microeconomic systems is substantiated. It is proposed to use mathematical tools for the analysis of hierarchies, based on mathematical and cognitive judgments based on the T. Saaty model. Application of the Pareto model for the distribution of the coefficients influence in the effectiveness of the components analysis of the potential profile is presented. The choice of innovation and investment strategies for the modernization potential development for enterprises in the infrastructure sector of Ukraine is analyzed and determined.
\end{abstract}

Key-Words: - innovation strategy, investment strategy, development, potential, modernization, cognitive analysis, analysis of hierarchies, PIIIS model, enterprises; microeconomic system

Received: February 20, 2021. Revised: July 16, 2021. Accepted: July 28, 2021. Published: August 8, 2021. 


\section{Introduction}

Within the innovation-cognitive paradigm, the modernization of microeconomic systems occurs with many prognostic scenarios and the lack of sufficient theoretical basis to explain future changes. In these conditions, the priority is innovation and investment strategies that meet the level of capacity development, the conditions of the internal and external environment, and the priorities of modernization change. At the same time, it is necessary to reconcile the goal of activating modernization potential with the achieved level of its implementation profile and the cost of innovation and investment projects. Therefore, the urgent problems are the development of tools to justify strategic preferences in developing potential of economic systems.

\section{Literature review}

Many domestic and foreign scientists have devoted their research to the study of various issues for the development of innovation and investment strategies, as well as investment support models, including: Aleksandrova O. (2020) [1], Astanakulov O.T., Asatullaev K.S. (2019) [2], Burak P., Khadzhynova O., Gonchar V., Kalinin O. (2019) [3], Dubyna M., Zhavoronok A., Kudlaieva N., Lopashchuk I. (2021) [4], Eldar A.G. (2020) [5], Ivanova N., Zhuk O. (2020) [6], Dergaliuk B., Tkachenko T. (2021) [7], Liu G., Cao H., Zhu G. (2021) [8], Madiyarova D., Luniewski A., Ibraeva A. (2019) [9], Matveeva M.V., Kalyuzhnova N.Y. (2019) [10], Revko A., Butko M. (2020) [11], Saaty Thomas Lorie, Luis G. Vargas (2001) [12], Shevchuk N., Chornii V., Chornii B. (2018) [13], Shkarlet S., Shtyrhun K. (2020) [14], Shynkaruk L., Ivanchenkova L., Kychko I. (2020) [15], Voytolovskiy N., Pogodina V., Ivanova M. (2020) [16], Zagorcheva D.P., Pavlov D.Y. (2020) [17], Zakharin S., Stoyanova-Koval S. (2021) [18] and others.

The aim of the article by Bulgarian scholars D. Zagorcheva and D. Pavlov is to show how the economic model of assessing the local business environment can be applied to some cities in Bulgaria on the basis of the municipal tax system and local investment policy. Thus, entrepreneurs would be able to compare business environment in different municipalities, as well as to determine possible dynamics of their trends [18].

The results obtained in the article of Aleksandrova O. mean that the behavior of farmers' investments is determined by competitive conditions of the product market and the ability of farms to sell products and invest in this market environment. Moreover, with the exception of all farms, gross investment is positively and significantly related to cash flow, which confirms absence of soft budget constraints for farms [1].

The main purpose of the article of Eldar A. is to outline the problems of modeling investment and financial support of regional socio-economic development, as well as to analyze the conceptual practical approach to these problems and to identify adequate mechanisms. Scientists analyzed the importance of financial and investment support in modeling socio-economic development at the regional level, the most rational use of local natural and economic reserves in the formation of financial resources and the modeling of enterprises. The authors have developed a structure for the formation and implementation of the regional investment policy [5].

The relevance of the research of scientists Matveeva M. and Kalyuzhnova N. is based on the main role of investment in new economic reality and the importance of intensifying investment activity in the modern state, including using state regulation of investment activity as state support. As a result, the relationship between government spending on investment support, fixed capital investment in the region's economy and investment attractiveness of the region; the most promising areas of the management system development of state support for investment activities at the regional level [10].

The purpose of the article by Astanakulov O., Asatullaev K., Saidaxmedova N. and Ergashev O. is to consider the organizational and economic mechanism of formation of investment policy companies. Scientists used general scientific and private methods of the analysis, i.e.: works of domestic and foreign scientists, monographs, lectures, periodicals, as well as laws and regulations, statistical information. The algorithm of the investment strategy of machine-building enterprise of the region was proposed [2].

The manuscript of Burak P., Khadzhynova O., Gonchar V. and Kalinin O. is devoted to the study 
of marketing support in the economic security system of the state. Initially, the data confirming the influence of marketing mechanisms of investment activities were presented. In addition, ways to effectively conduct investment activities based on marketing and economic security were proposed [3].

The aim of the study of Chinese scientists Liu G., Cao H. and Zhu G. is to research the impact of farsighted and short-sighted behavior of competing companies on consumer perceptions of the product's environmental friendliness on their pricing and innovative investment strategies and profits. The authors came to the following conclusions. First, when one company is far-sighted and another is short-sighted, the latter yields more profit than the former if the innovative investments of one company have a relatively small direct impact on the demand of another. Second, when the intensity of competition for innovative investments of two companies is not strong, competition with a farsighted competitor can make the company better. Third, the scenario where both companies adopt farsighted strategies can reach equilibrium, while existing short-sighted strategies can bring greater profits to both under certain conditions [8].

The purpose of the work of Voytolovskiy N., Pogodina V. and Ivanova M. is to develop a strategy for managing innovation and investment activities of industrial enterprises at different stages of its life cycle. Based on the analysis and evaluation of the effectiveness of the existing strategies implementation, relevant features of innovation and investment activities of enterprises were identified. Scientists have developed a methodological approach to assessing the meso- and macroeconomic effect of the enterprise transformation depending on the stage of the life cycle and the algorithm for determining the optimal development strategy, which is based on the analysis of the parameters of the predicted stability [16].

The authors Madiyarova D., Luniewski A. and Ibraeva A. present trends in increasing economic efficiency of the optimization of investment and innovation potential of industrial enterprises. It is concluded that its assessment is a procedure that allows to present objective results of evaluated enterprises, both current and future, obtained during the implementation of the overall development strategy by influencing different groups of efficiency factors [9].

\section{Methodology}

The modeling of innovation and investment development of modernization potential of economic systems in the study is based on the provisions of the innovation and cognitive paradigm. As the basic scientific concept, strategic management was chosen, which corresponds to the set goals of establishing preferences and hierarchies of innovation and investment strategies and levels of the profile of modernization potential. During the study, methods of hierarchies of T.S. Saaty, Pareto distribution, as well as cognitive-expert research, mathematical sequence of indicators were used.

\section{Results}

According to the authors, exclusive innovation and investment strategies of microeconomic systems include:

- firstly, strategies of creative, progressive, competitive development of microeconomic systems;

- secondly, functional innovation and investment strategies, which may include - logistics, financial, personnel, product and other strategies;

- thirdly, strategies for transformation, restructuring and adaptation;

- fourthly, the strategy of innovation and technological renewal.

To justify the choice of an exclusive innovation and investment strategy, it is advisable, in the opinion of the authors, to build an algorithm for making management decisions on the model of "preferences in the implementation of investment and innovation strategies" ("PIIIS"). The PIIIS model is based on the strategic analysis of the direction of the modernization opportunities implementation in accordance with the achieved level of the enterprise modernization (Fig. 1). 


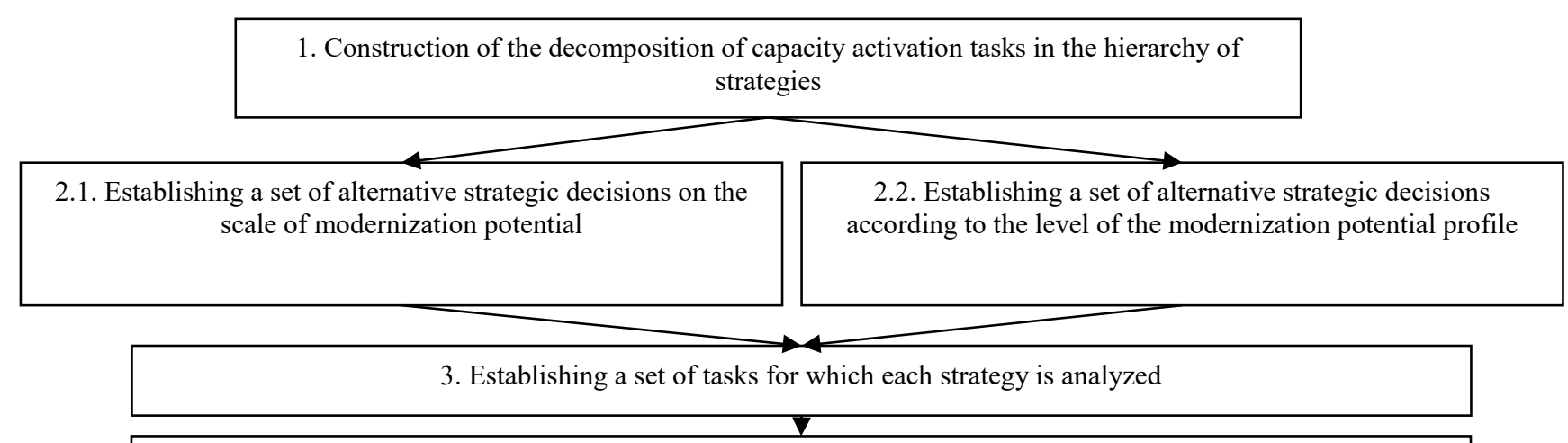

4. The priority of tasks at a choice of strategies with the application of pair estimations of judgments is defined

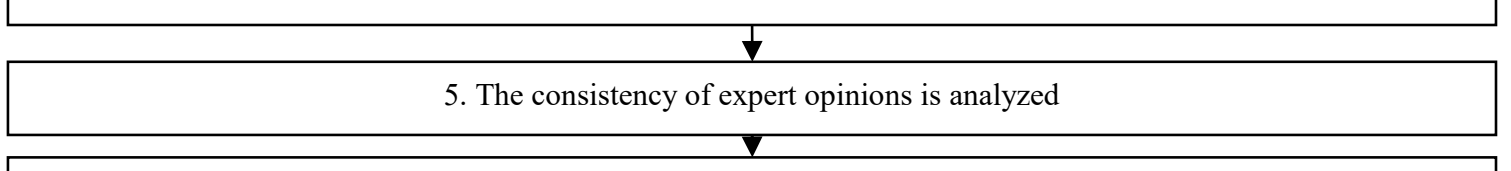

6. A matrix of pairwise comparisons of judgments about the importance of tasks and setting priorities is built

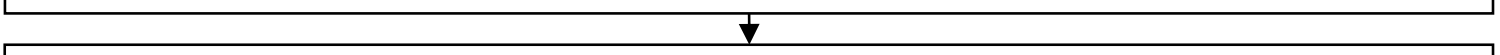

7. The priority of alternatives for each task is determined

8. The priority strategy corresponding to the strategic decision is defined.

Figure 1: The sequence of establishing preferences for innovation and investment strategies to enhance Source: developed by the authors modernization potential of microeconomic systems

The PIIIS model reveals the mechanism for selecting innovation and investment strategies for further application in the implementation of modernization potential and designs a system for allocating resources between strategies.

To model the process of giving preferences to innovation and investment strategies, we use mathematical tools for the analysis of hierarchies authored by T. Saaty, based on mathematical and cognitive judgments [12].
The decomposition of the tasks of granting preferences to innovation and investment strategies to intensify modernization potential of microeconomic systems is presented in Fig. 2, and has the following form:

$$
I 0 \subseteq\{I 11 ; I 12 ; I 13 ; I 14\}
$$

where I1 1 - component of resource provision;

I1 2 - component of accumulation;

I13 - component of implementation;

I14 - component of effectiveness. 


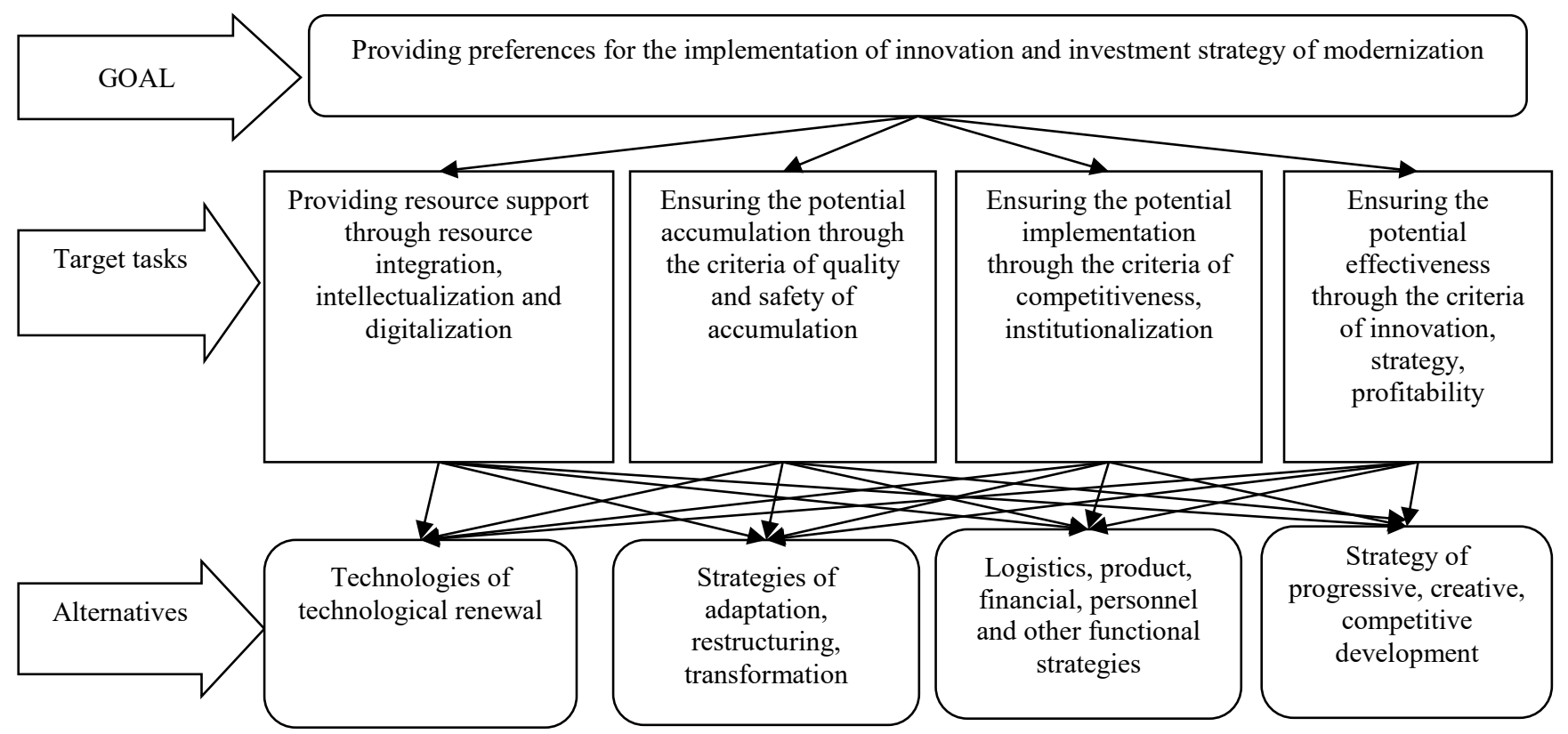

Figure 2: Decomposition of tasks of granting preferences to innovation and investment strategies of the modernization potential activation of microeconomic systems

Source: developed by the authors

Revealing the content of each component, we formalize their structure:

$$
\begin{aligned}
& I 11 \subseteq(K 1, \ldots K 5) ; \\
& I 12 \subseteq(K 6, \ldots K 10) ; \\
& I 13 \subseteq(K 11, \ldots K 15) ; \\
& I 14 \subseteq(K 16, \ldots K 18) ;
\end{aligned}
$$

where $\mathrm{K} 1 \ldots \mathrm{K} 18$ - corresponding coefficients of the analysis of the modernization potential state according to the established levels.

At the stage of prioritization of tasks when choosing strategies it is necessary to justify the choice of each coefficient and establish their importance. For this purpose, a matrix of pairwise comparisons with respect to each coefficient is constructed (Table 1). In the matrix, the importance of the hierarchy of the Saaty factor and over the factor $j$ on the scale of intensity from 1 to 9 :

- 1 - equal importance;

- 3 - moderate dominance of the i-th factor on j-th;

- 5 - significant advantage of the i-th factor on j-th;

- 7 - significant advantage of the i-th factor on j-th;

- 9 - very strong advantage of the i-th factor over j-th [12].

In Table 1, the operator $R=\left(x_{i 1} \succ x_{i 2}\right)$ rotates the numerical values of relative importance. Conversely, if $x_{i 1} \prec x_{i 2}$ - inverse values are used. Each studied coefficient receives certain values of $a$ $(i ; j)$, while $\mathrm{M}$ is the maximum value of the judgment.

Table 1: Matrix of pairwise comparisons of relative importance of coefficients in each component $I$

\begin{tabular}{|l|l|l|l|l|l|l|}
\hline & $x_{1}$ & $x_{2}$ & $\ldots$ & $x_{i 2}$ & $\ldots$ & $x_{M}$ \\
\hline$x_{1}$ & 1 & $a_{12}=R\left(x_{1} \succ x_{2}\right)$ & $\ldots$ & $a_{1 i_{2}}=R\left(x_{1} \succ x_{i_{2}}\right)$ & $\ldots$ & $a_{1 M}=R\left(x_{1} \succ x_{M}\right)$ \\
\hline$x_{2}$ & $a=1 / a_{12}$ & 1 & $\ldots$ & $a_{2 i_{2}}=R\left(x_{2} \succ x_{i_{2}}\right)$ & $\ldots$ & $a_{2 M}=R\left(x_{2} \succ x_{M}\right)$ \\
\hline$\ldots$ & $\ldots$ & $\ldots$ & $\ldots$ & $\ldots$ & $\ldots$ & $\ldots$ \\
\hline$x_{i l}$ & $a_{i l 1}=1 / a_{I i l}$ & $a_{i l 2}=1 / a_{2 i l}$ & $\ldots$ & $a_{i l i 2}=1 / a_{I i l}$ & $\ldots$ & $a_{i_{1} M}=R\left(x_{i_{1}} \succ x_{M}\right)$ \\
\hline$\ldots$ & $\ldots$ & $\ldots$ & $\ldots$ & $\ldots$ & $\ldots$ & $\ldots$ \\
\hline$x_{M}$ & $a_{M 1}=1 / a_{l M}$ & $a_{M 2}=1 / a_{I M}$ & $\ldots$ & $a_{M i_{2}}=1 / a_{i_{2} M}$ & $\ldots$ & 1 \\
\hline
\end{tabular}

Source: suggested by the authors 
The set of coefficients for the analysis of the level of the modernization potential implementation is grouped into four groups. This corresponds to the given structure of tasks and levels of the potential impementation (Table 1).

The use of cognitive-expert assessment requires the use of additional tools to establish the consistency of assessments. This is set by the following conditions:

$$
\frac{\lambda_{\max }-M}{M-1} \rightarrow 0
$$
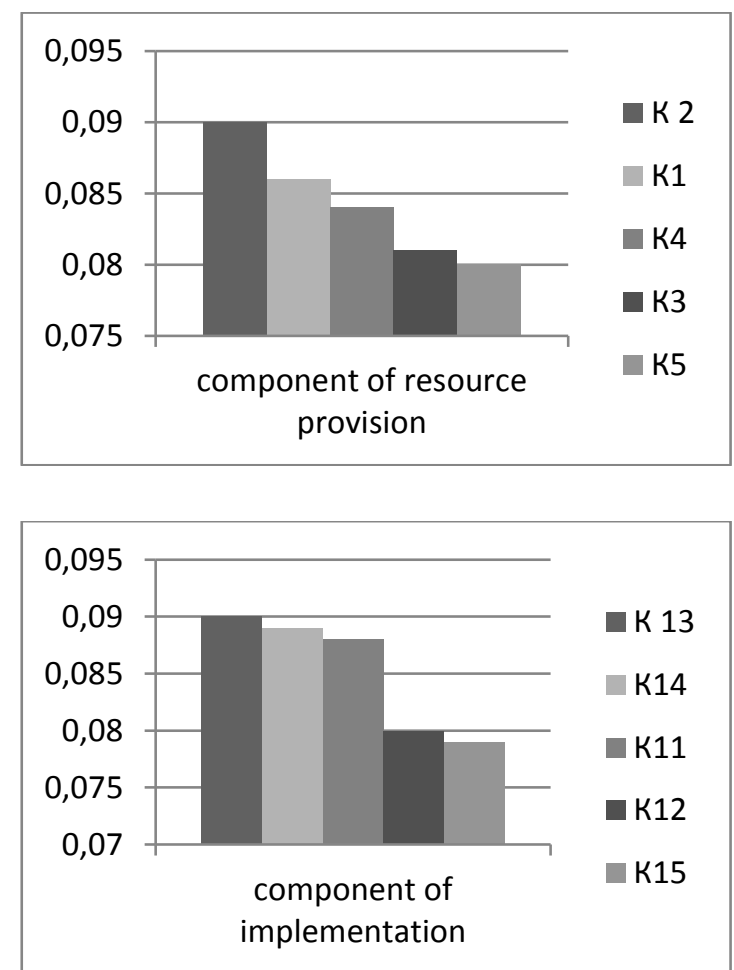

$$
\lambda_{\max }=\left(b_{1}, b_{2}, \ldots b_{i 2}, b_{M}\right) \times\left(\begin{array}{c}
w_{1} \\
w_{2} \\
\cdots \\
w_{i} \\
\cdots \\
w_{M}
\end{array}\right)
$$

where $\mathrm{w}$ - vector of normalized weights.

Calculations showed that the average consistency of cognitive judgments is -0.088 . In Fig. 3, values and hierarchy of the influence distribution of coefficients on the effectiveness of the analysis of the modernization potential development.
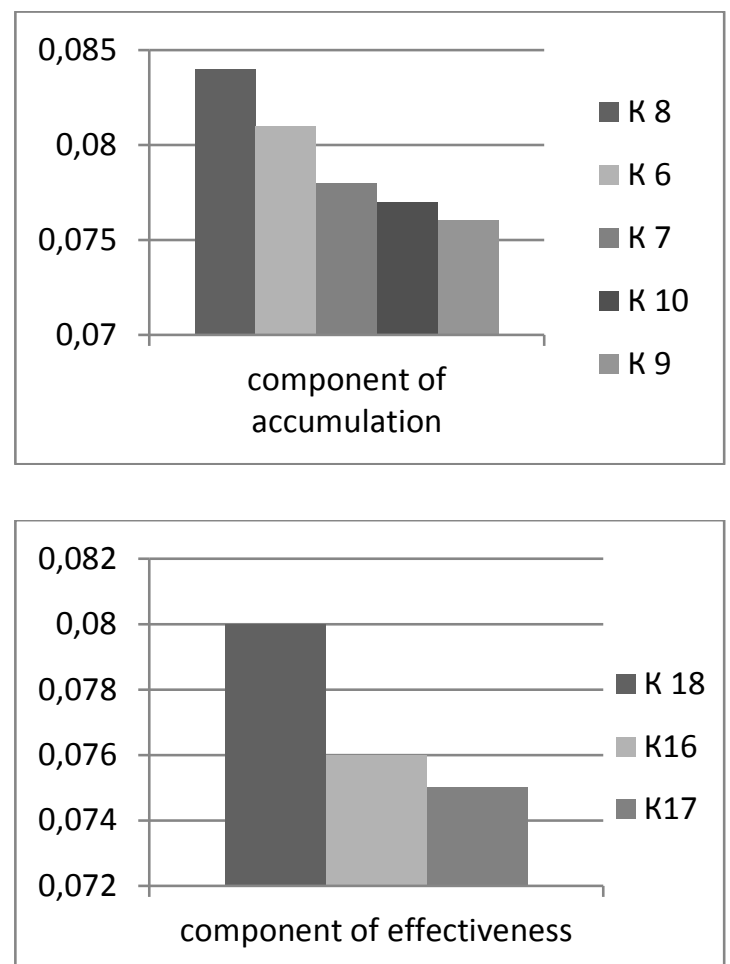

Figure 3: Distribution of the influence of coefficients on the effectiveness of the analysis of the modernization potential development according to the Paretto model

Source: constructed by the authors based on the evaluation results

Thus, cognitive judgments of experts coincide by $(1-0.088) 100 \%=91.2 \%$. This value is acceptable to take into account the results of expert research. coefficients for the analysis of the implementation level of the modernization potential profile in Table 2.

Therefore, we present a set of reasonable

\begin{tabular}{|c|c|}
\hline Indicator & Calculation of indicators \\
\hline \multicolumn{2}{|r|}{ Resource and project component (I11) } \\
\hline K1. Profitability of the main activity & The ratio of profit to the cost of products / services \\
\hline K2. Return on capital & The ratio of profit to the value of equity \\
\hline K3. Autonomy of capital & The ratio of equity to the balance sheet \\
\hline K4. Productivity & The ratio of production to staff \\
\hline K5. Return on fixed assets & The ratio of profit to the residual value of fixed assets \\
\hline \multicolumn{2}{|r|}{ Accumulating component (I12) } \\
\hline K6. Return on investment & The ratio of profit to the value of investments \\
\hline
\end{tabular}

Table 2: The set of coefficients for estimating the profile of modernization potential 


\begin{tabular}{|l|l|} 
K7. Capitalization & Calculated as the sum of the rate of return on capital and the rate of credit. \\
\hline $\begin{array}{l}\text { K8. Dynamics of the potential cost } \\
\text { growth }\end{array}$ & $\begin{array}{l}\text { The ratio of the value of economic potential in the current year to the previous } \\
\text { period }\end{array}$ \\
\hline K9. Capacity structure & $\begin{array}{l}\text { The sum of tangible and intangible resources is compared with the value of all } \\
\text { assets }\end{array}$ \\
\hline K10. Investment mobility & The ratio of the value of current assets to the balance sheet \\
\hline \multicolumn{2}{|c|}{ Component of potential implementation (I13) } \\
\hline K11. Innovation & Weighted average score by parameters \\
\hline K12. Intellectualism & Weighted average score by parameters \\
\hline K13. Quality & Weighted average score by parameters \\
\hline K14. Safety & Weighted average score by parameters \\
\hline K15. Digitization & Weighted average score by parameters \\
\hline $\begin{array}{l}\text { K16. Capacity implementation } \\
\text { efficiency }\end{array}$ & $\begin{array}{l}\text { Component of capacity effectiveness (I14) } \\
\text { modernization changes with the adjusted cost of the functional potentials } \\
\text { implementation and taking into account the effects of qualitative parameters }\end{array}$ \\
\hline K17. Integration & Calculated as a weighted average score for speed, stability and spaciousness \\
\hline K18. Modernization pace & The ratio of costs for modernization in the current year to the previous period \\
\hline
\end{tabular}

Source: suggested by the authors

We will focus our research on determining the priority innovation and investment strategy to enhance modernization potential of the enterprise.
To do this, we compose expert-cognitive judgments in an inversely symmetric matrix on the influence on the components of the potential profile (Table 3).

Table 3: Matrix of paired expert-cognitive judgments on the choice of innovation and investment strategy of the enterprise modernization by the T.Saaty method of analysis of hierarchies

\begin{tabular}{|c|c|c|c|c|c|c|}
\hline Target tasks & $\begin{array}{l}\text { Providing resource } \\
\text { support through } \\
\text { resource } \\
\text { integration, } \\
\text { intellectualization } \\
\text { and digitalization }\end{array}$ & $\begin{array}{l}\text { Ensuring the } \\
\text { potential } \\
\text { accumulation } \\
\text { through the } \\
\text { criteria of quality } \\
\text { and safety of } \\
\text { accumulation }\end{array}$ & $\begin{array}{l}\text { Ensuring the } \\
\text { potential } \\
\text { implementation } \\
\text { through the criteria } \\
\text { of competitiveness, } \\
\text { institutionalization }\end{array}$ & $\begin{array}{c}\text { Ensuring the } \\
\text { potential } \\
\text { effectiveness through } \\
\text { the criteria of } \\
\text { innovation, strategy, } \\
\text { profitability }\end{array}$ & $\mathrm{W}_{\mathrm{i}}$ & $\mathrm{W}_{\text {norm }}$ \\
\hline $\begin{array}{l}\text { Providing resource } \\
\text { support through } \\
\text { resource integration, } \\
\text { intellectualization and } \\
\text { digitalization }\end{array}$ & 1 & 3 & 7 & 9 & 20 & 0,486 \\
\hline $\begin{array}{l}\text { Ensuring the potential } \\
\text { accumulation through } \\
\text { the criteria of quality } \\
\text { and safety of } \\
\text { accumulation }\end{array}$ & $1 / 3$ & 1 & 5 & 7 & 13,33 & 0,32 \\
\hline $\begin{array}{l}\text { Ensuring the potential } \\
\text { implementation } \\
\text { through the criteria of } \\
\text { competitiveness, } \\
\text { institutionalization }\end{array}$ & $1 / 7$ & $1 / 5$ & 1 & 5 & 6,34 & 0,16 \\
\hline $\begin{array}{l}\text { Ensuring the potential } \\
\text { effectiveness through } \\
\text { the criteria of } \\
\text { innovation, strategy, } \\
\text { profitability }\end{array}$ & $1 / 9$ & $1 / 7$ & $1 / 5$ & 1 & 1,45 & 0,06 \\
\hline Total & 1,586 & 4,343 & 13,2 & 22 & 41,12 & 1 \\
\hline
\end{tabular}

Source: calculated by the authors 
The assessment conducted at the enterprises of Ukraine belonging to the infrastructure sphere showed that the priority innovation and investment strategies are the strategy of progressive, creative, competitive development.

This is in line with the objectives of ensuring the modernization potential effectiveness of enterprises. However, it is necessary to remember that the goal of activating modernization potential is consistent with the availability of resources, the level of its implementation and the cost of activating certain innovation and investment strategies. This affects the overall costs and results of the modernization process and creates the cost of implemented technologies or modernized facilities.

\section{Conclusion}

The study allowed to improve economic and mathematical tools for analyzing the system of indicators for assessing the profile of the modernization potential development. The constructed sequence of establishing preferences of innovation and investment strategies, highlighting the tasks and levels of the modernization potential development allowed to establish the basic conditions of the model "preferences in the implementation of investment and innovation strategies". The constructed system of coefficients of the analysis of the modernization potential profile of economic systems is based on the conducted estimation of cognitive judgments and their mutual coherence. This allowed to offer economic and mathematical tools to substantiate the priority vector for choosing an innovation and investment strategy. Applied studies of the implementation of the proposed toolkit proved its practical significance and allowed to determine that for the modernization potential development of enterprises in the infrastructure sector of the Ukrainian economy it is necessary to apply progressive, creative and competitive strategies.

\section{References:}

[1] Aleksandrova O., Soft budget constraints and investment support in Estonian agriculture, HSE Economic Journal, Vol. 24, Is. 1, 2020, pp. 85-100.

[2] Astanakulov O.T., Asatullaev K.S., Saidaxmedova N.I., Ergashev O.T., Strategic support for accounting for the investment process in the innovation industry, Journal of Advanced Research in Law and Economics, Vol. 10, Is. 6, 2019, pp. 1877-1883.

[3] Burak P., Khadzhynova O., Gonchar V., Kalinin O., Mechanisms of investment marketing support of the state economic security system, Intellectual Economics, Vol. 13, Is. 2, 2019, pp. 161-171.

[4] Dubyna M., Zhavoronok A., Kudlaieva N., Lopashchuk I., Transformation of household credit behavior in the conditions of digitalization of the financial services market, Journal of Optimization in Industrial Engineering, Vol. 14(1), 2021, pp. 97-102.

[5] Eldar A.G., Problems of financial and investment support modelling of the regional social and economic development, WSEAS Transactions on Business and Economics, Vol. 17, 2020, pp. 741-752.

[6] Shkarlet S., Ivanova N., Popelo O., Dubina M., Zhuk O., Infrastructural and Regional Development: Theoretical Aspects and Practical Issues, Studies of Applied Economics, Vol. 38-3(1), 2020.

[7] Popelo O., Tulchynska S., Kharchenko Y., Dergaliuk B., Khanin S., Tkachenko T., Systemic Approach to Assessing Sustainable Development of the Regions, Journal of Environmental Management and Tourism, Vol. XII, No. 3(51)), 2021, pp. 742-753.

[8] Liu G., Cao H., Zhu G., Competitive pricing and innovation investment strategies of green products considering firms' farsightedness and myopia, International Transactions in Operational Research, Vol.28, Is. 2, 2021, pp. 839-871.

[9] Madiyarova D., Luniewski A., Ibraeva A., Advancing competitiveness and developing the innovation and investment potential of industrial enterprises using cluster strategies, Journal of Advanced Research in Law and Economics, Vol. 10, Is. 8, 2019, pp. 24172428.

[10] Matveeva M.V., Kalyuzhnova N.Y., Industrial Construction: Investment Support in Entrepreneurship, IOP Conference Series: Materials Science and Engineering, Vol. 667, Is. 1, 29 November 2019, 012062.

[11] Revko A., Butko M., Popelo O., Methodology for Assessing the Inflence of Cultural Infrastructure on Regional Development in Poland and Ukraine, Comparatie Economic Research. Central and Eastern Europe, Vol. 23(2), 2020, pp. 21-39.

[12] Saaty Thomas Lorie \& Luis G. Vargas, Models, Methods, Concepts \& Applications of the Analytic Hierarchy Process, Kluwer Academic, 2001.

[13] Tulchynska S., Shevchuk N., Chornii V., Chornii B., Using a methodical approach to the 
evaluation of attractiveness investment resources for electricity distribution companies, Naukovyi Visnyk NHU, No. 2, 2018, pp. 130135.

[14] Shkarlet S., Dubyna M., Shtyrhun K., Transformation of the Paradigm of the Economic Entities Development in Digital Economy, WSEAS TRANSACTIONS on ENVIRONMENT and DEVELOPMENT, Vol. 16, 2020, pp. 413-422.

[15] Shynkaruk L., Ivanchenkova L., Kychko I., Kartashova O., Melnyk Y., Ovcharenko T. Managing the economy's investment attractiveness of the state as a component of international business development, International Journal of Management (IJM), Vol. 11, Is. 5, 2020. pp. 240-251.

[16] Voytolovskiy N., Pogodina V., Ivanova M., Management strategy for innovation and investment activities of an enterprise, E3S Web of Conferences, Vol. 1645, May 2020, 10051.

[17] Zagorcheva D.P., Pavlov D.Y., Dynamic estimation of the local business environment in support to investment decisions of the top managers, Serbian Journal of Management, Vol. 15, Is. 2, 2020, pp. 263-275.

[18] Zakharin S., Stoyanova-Koval S., Kychko I., Marhasova V., Shupta I. Strategic Management of the Investment Process in the Agricultural Sector (for Example, Agricultural Enterprises and the Food Industry), Journal of Optimization in Industrial Engineering (JOIE), Vol. 14, Is. 1, 2021, pp. 209-218.

\section{Creative Commons Attribution License 4.0 (Attribution 4.0 \\ International, CC BY 4.0)}

This article is published under the terms of the Creative Commons Attribution License 4.0 https://creativecommons.org/licenses/by/4.0/deed.en US 